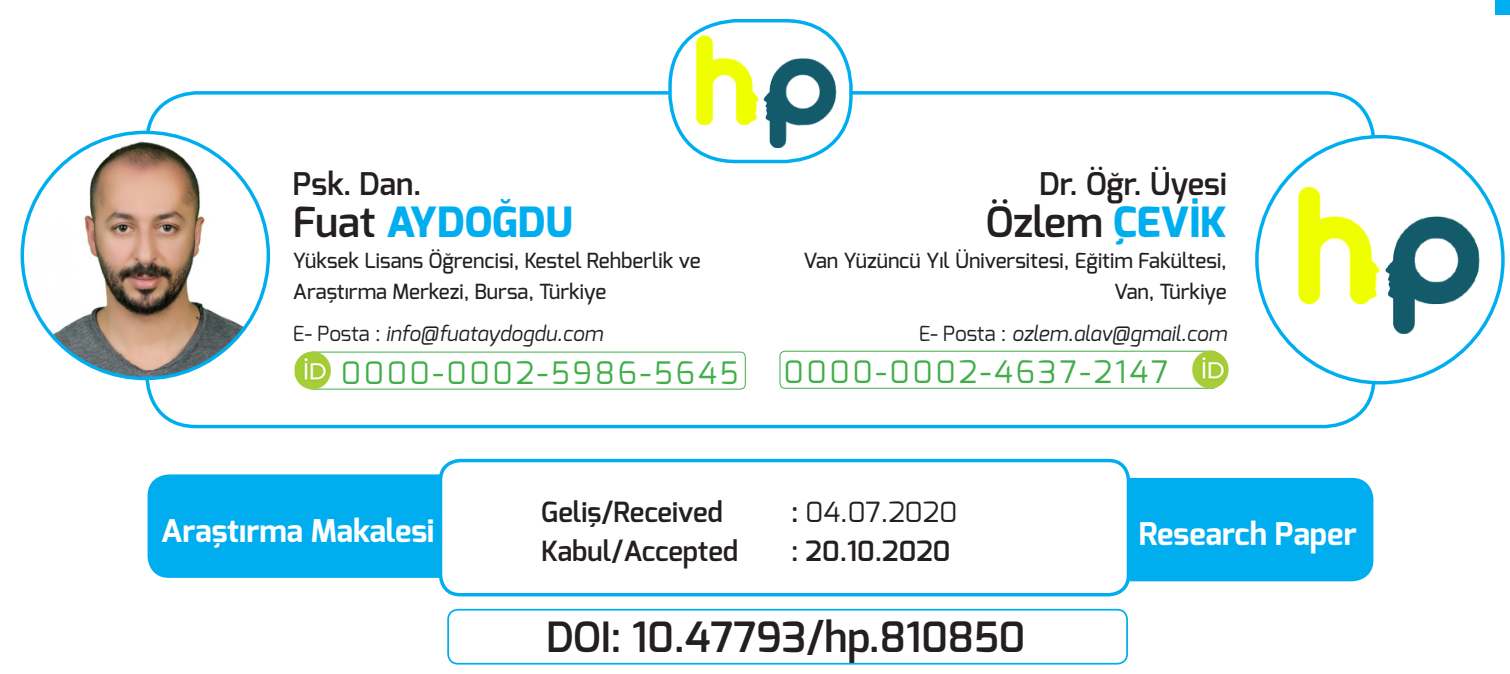

\title{
Okul Psikolojik Danışmanlarının Sosyotelist Davranışlarının, Sosyotelizme Maruz Kalma ve Yalnızlık Düzeyleri Üzerindeki Etkisinin İncelenmesi
}

\section{ÖZET}

$\mathrm{Bu}$ araştırmada okul psikolojik danışmanlarının sosyotelist davranışlarının, sosyotelizme maruz kalma ve yalnızlıkları üzerindeki etkisinin anlamlılığını ortaya koymak amaçlanmıştır. Araştırmanın çalışma grubunu 2019 - 2020 eğitim öğretim yllında Muş ilinde görev yapmakta olan anaokulu, ilkokul, ortaokul ve liselerde çalışan 115 okul psikolojik danışmanı oluşturmaktadır. İlişkisel tarama metodu kullanılan bu araştırmada veriler, "Demografik Bilgi Formu", "UCLA Yalnızlık Ölçeği", "Genel Sosyotelist Olma Ölçeği" ve "Sosyotelizme Maruz Kalma Ölçeği" ile toplanmıştır. Toplanan veriler SPSS 22.0 programında analiz edilmiştir. Araştırmada okul psikolojik danışmanlarının genel sosyotelist olma puanları ve genel sosyotelizme maruz kalma puanları medeni durum ve cinsiyet açısından bağımsız örneklem t testi ile karşılaştırılmış ancak anlamlı fark bulunamamıştır. Yapılan analizler sonucunda Pearson Çarpım Momentler Korelasyon katsayısı ile değişkenler arasında ilişki incelenmiş olup genel sosyotelist olma ile yalnızlık ve genel sosyotelist olma ile genel sosyotelizme maruz kalma arasında pozitif yönlü anlamlı ilişki bulunmuştur. Yapılan basit regresyonlar sonucunda okul psikolojik danışmanlarının genel sosyotelist davranışlarının, yalnızlıklarını ve sosyotelizme maruz kalmalarını anlamlı bir şekilde yordadığı saptanmışır. Araştırmadaki bulgular alanyazında sosyotelizmle ilgili yapılan diğer araştırmalarla karşılaştırılarak tartışılmış ve araştırmacılara çeşitli önerilerde bulunulmuştur.

Anahtar Kelimeler: sosyotelizm, sosyotelist, sosyotelizme maruz, kalma, yalmalık, psikolojik danısman

\section{The Examination of The Effect of Phubbing Behaviors of School Psychological Counselors on Being Phubbed and Loneliness}

\begin{abstract}
In this study, it was aimed to reveal the significance of the effect of the phubbing behaviors of school psychological counselors on being phubbed and loneliness. The study group of the research consists of 115 psychological counselors working in kindergarten, primary school, middle school and high schools working in Muş province in the 2019-2020 academic year. In this research using relational survey model, the data were collected with "Demographic Information Form", "UCLA Loneliness Scale", Generic Scale of Phubbing (GSP) and Generic Scale of Being Phubbed (GSBP). The collected data were analyzed using IBM SPSS 22 program. The difference depending on marital status and gender in general phubbing scores and the general being phubbed scores of psychological counselors were examined using Independent Samples t Test, however there was no significant difference found. According to the Pearson Correlation Coefficient, it is found out that there is a positive correlation between phubber, loneliness, general phubber and being phubbed. As a result of two separated Simple Linear Regression tests, it was determined that the general phubbing behaviors of psychological counselors' significantly predicted their levels in loneliness and being phubbed. Results of the study were discussed by comparing the studies about phubbing in literature and various suggestions were made for researchers.
\end{abstract}

Keywords: phubbing, phubber, phubbee, being phubbed, loneliness, psychological counselor 
Ekim 2020, Cilt 2, Sayı 3

October 2020, Volume 2, Issue 3
İletișim / Contact

Mail : info@humanisticperspective.com Web : https://dergipark.org.tr/tr/pub/hp

\section{GİRİŞ}

Y aşamın her alanına sızmış ve en küçük uygulamadan en büyük uygulamaya kadar yaşamımızda yerini koruyan teknoloji, hızla gelişmekte ve ilerlemektedir. Evde, okulda, sokakta, iş yerinde ve neredeyse insanın olduğu her yerde kendine yer bulabilen teknoloji ve teknoloji destekli araçlar insanlara büyük kolaylıklar sunduğu gibi birçok problemi de beraberinde getirmektedir. Sosyalleşme, eğlence ve gündelik işlerde kullanımıyla birincil amacından uzaklaşan akıllı telefonlar (Orhan Göksün, 2019), insan hayatını kolaylaştırmanın yanı sıra olumsuz da etkilemektedir. İnsan hayatını bağımlılık, davranış bozukluğu, uykusuzluk gibi sorunlarla etkileyen akıllı telefonların yoğun kullanımının bir diğer olumsuz etkisi de sosyotelizmdir (Büyükgebiz Koca, 2019). Sosyotelizm, yüz yüze iletissim halinde olan en az iki kişiden birinin akı1lı telefonuyla kişilerarası iletişimden daha fazla etkileşim halinde olması (Chotpitayasunondh ve Douglas, 2016) algısını kişilerarası iletişimden uzaklaştırmasıdır (Karadağ vd., 2016). Daha basit bir ifadeyle sosyotelizm, aynı ortamda bulunan bireylerin iletişimi sürdürmekten ziyade telefonları ile ilgilenmesi ve bu nedenle iletissimden kopması durumudur (Özdemir, 2020).

Telefon bağımlılı̆̆ının bir alt türü olan sosyotelizmin (Büyükgebiz Koca, 2019) oyun bağımlılığ1, telefon bağımlılığı, internet bağımlılığ1 gibi diğer bağımlılıklarla iç içe girmiştir (Büyükgebiz Koca, 2019; Karadağ vd., 2016). Alanyazında yeni bir kavram olan sosyotelizm kendinden önceki bağımlılıklardan daha sinsi ve tehlikeli bir bağımlılık olarak görülmekte ve sosyotelizmin depresyon ve başka zihinsel sorunlar gibi ciddi psikopatolojik ve sosyolojik problemlere neden olabileceği düşünülmektedir (Karadă̆ vd., 2016; Afdal, Ifdil, Alizamar ve Ardi, 2019). Bu nedenle sosyotelizmin neden olduğu durumları ve sosyotelizmle ilişkili kavramları bilmek önemlidir.

Ülkemizde üniversitelerin Psikolojik Danışma ve Rehberlik Anabilim Dallarından mezun olan bireyler "psikolojik danışman” unvanı alır ve Milli Eğitim Bakanlığı’na bağlı özel ve devlet okullarında okul psikolojik danışmanlığı görevini yürütürler (Özteke Kozan, 2020). Okul psikolojik danışmanları Milli Eğitim Bakanlığı Rehberlik Hizmetleri Yönetmeliğinde "Rehberlik Öğretmeni” olarak kadro unvanı alırlar (Milli Eğitim Bakanlığı [MEB], 2017). Okullarda yürütülen rehberlik ve psikolojik danışma hizmetlerinden sorumlu olan okul psikolojik danışmanları, psikolojik danışma, oryantasyon, bireyi tanıma, bilgi toplama ve yayma, yöneltme ve yerleştirme, izleme ve değerlendirme ve müşavirlik hizmetleri gibi sorumlulukları belirli etik ilkeler 1şı̆̆ında yaparlar (Yeşilyaprak, 2010). Görev ve sorumlulukları bakımından değerlendirildiğinde okullardaki görevlerini sürdüren okul psikolojik danışmanlarının etki alanı oldukça kapsamlıdır. Bu açıdan bakıldığında alanyazında sosyotelizm gibi yeni bir kavramın görev ve sorumluluklarını yerine getirmeye çalışan okul psikolojik danışmanlarını da olumsuz etkileyeceği düşünülmektedir. Bu araştırmada okul psikolojik danışmanlarının sosyotelist davranışları ile yalnızlık ve sosyotelizme maruz kalma durumlarının ilişkisini araştırmak amaçlanmıştır.

Araştırmanın temel değişkenlerinden olan yalnızlık, bireyin istediği sosyal ilişki düzeyine erişememesine bağlı olarak yaşamış olduğu olumsuz duygu durum olarak tanımlanır (Demirbaş ve Haşit, 2016). Yalnızlık duygusunu yoğun olarak yaşayan bireylerin iş hayatlarında sağlıklı ilişkiler sürdürmesi, psikolojik ve zihinsel olarak iyilik halinde olması güçtür (Yakut ve Certel, 2016). Okul- 
larda bireyle ve grupla psikolojik danışma hizmetinin yanı sıra okul rehberlik hizmetlerini yürütmede anahtar konumda olan okul psikolojik danışmanlarının, okulda yönetim, öğretmen, öğrenci ve veli ile kapsamlı etkileşiminin olduğu düşünüldüğünde yalnızlık duygusunu daha geniş bir çevreye yansıtmaları olasıdır. Ayrıca bu duyguyu yoğun olarak yaşayan psikolojik danışmanların iş performansları düşebilir. Sosyotelizmle ilgili yapılan çalışmalar, yalnızlık ile sosyotelizm arasında güçlü bir ilişkinin olabileceğine işaret etmektedir (Karadağ vd., 2016; Mert ve Özdemir, 2018). Fakat sosyotelizmle ilgili çok çalışma olmadığı için konuyla ilgili daha fazla çalışmaya ihtiyaç vardır.

Gerçek hayatın sunduğu yüz yüze iletişimi sekteye uğratan sosyotelizmin insan ilişkilerini olumsuz olarak etkilemesi (Karadağ vd., 2016), sosyotelizmin olumsuz sonuçlarından biridir. Birinin sorununu dinlerken bile istemeyerek ellerine cep telefonunu alan bireyler karşıdaki bireyi dinler gibi görünse de aslında başka şeyler meşgul olarak (Büyükgebiz Koca, 2019) karşı tarafı sosyotelizme maruz bırakmaktadır ve sosyotelizme maruz bırakma çoğu zaman karşı tarafa kendini kötü hissettirmekte ve kendisinin veya sohbetin önemsenmediğini düşündürmektedir (Karadă̆ vd., 2016; Nazir ve Pişkin, 2016). Akıllı telefonlardaki uygulamalar aracılığıyla sosyalleşme olarak da bilinen sosyotelizm (Ünalan ve Yıldırım, 2020), gerçek yaşamı tehdit etmektedir. Ayrıca sosyotelizme maruz bırakma, bu haliyle kırıcı, kaba ve toplumsal normları ihlal gibi algılanmakta ve yakın ilişki, empatik ilgiye zarar vermektedir (Al-Saggaf ve O’Donnel, 2019).

Sosyotelizm ile ilgili araştırmalar incelendiğinde; sosyotelizmin bireyin iş, okul hayatı ve diğer ilişkilerini olumsuz olarak etkilediği görülmektedir. Ülkemizde yapılan bir araştırmada (Dikeç ve Kebapçı, 2018) öğrencilerin ak1llı telefon bağımlılık düzeyleri yüksek bulunmuştur. Öğrencilerin kişilik özellikleri ile sosyotelist davranışlara yol açan akıllı telefon bağımlılıkları arasında anlamlı ilişki bulunmuştur (Işik ve Kaptangil, 2018). Ayrıca internet bağımlılı̆̆ı, SMS kullanımı, cep telefonu ve sosyal medya ile sosyotelist olma arasında ilişki vardır (Karadağ, Tosuntaş, Erzen, Culha, Mızrak Şahin, Babadağ ve Duru, 2015) ve sosyotelist davranışlar kadınlarda daha fazladır (Karadağ vd., 2016).

\section{Çalışmanın Önemi ve Amacı}

Birçok meslekte kolaylaştırıcı bir rol sağlayan etkili iletişim becerileri, özellikle temeli yüz yüze iletişimi gerektiren mesleklerden biri olan psikolojik danışmanlıkta daha hâkim olunması gereken bir özellik olarak karşımıza çıkmaktadır (Korkut, 2005). Yüz yüze iletişime zarar veren sosyotelizmin (Karadă̆ vd., 2016; Büyükgebiz Koca, 2019) okul psikolojik danışmanlarındaki durumunu bilmek bu açıdan önemlidir. Literatürde oldukça yeni bir kavram olan sosyotelizmle ilgili yapılacak çalışmalar konunun anlaşılmasında önemlidir. Sosyotelizmle yapılan çalışmaların farklı örneklem gruplarıyla yapılması konunun anlaşılırlığı için gereklidir. Bu nedenle bu çalışmada okul psikolojik danışmanlarının sosyotelist olma durumları, sosyotelizme maruz kalma ve yalnızlık değisskenleriyle ilişkisini incelemek amaçlanmaktadır. Bu temel amaç doğrultusunda aşağıdaki sorulara yanıt aranmak istenmiştir:

1. Okul psikolojik danışmanlarının genel sosyotelist olma puanları cinsiyete ve medeni duruma göre farklılaşmakta midır?

2. Okul psikolojik danışmanlarının genel sosyotelizme maruz kalma puanları cinsiyete ve me- 
Illetișim / Contact

Mail : info@humanisticperspective.com Web : https://dergipark.org.tr/tr/pub/hp

deni duruma göre farklılaşmakta mıdır?

3. Okul psikolojik danışmanlarının genel sosyotelist olma ve yalnızlıkları puanları arasında anlamlı bir ilişki var mıdır?

4. Okul psikolojik danışmanlarının genel sosyotelist olma ve genel sosyotelizme maruz kalma puanları arasında anlamlı bir ilişki var mıdır?

5. Okul psikolojik danışmanlarının genel sosyotelist olma puanları, yalnızlık ve genel sosyotelizme maruz kalma puanlarını yordamakta midir?

Bireylerin yaşamlarını olumsuz etkileyen sosyotelizm üzerine yapılan çalışmaların sınırlı sayıda olması ve daha önce okul psikolojik danışmanları üzerinde bu konuyla ilgili bir çalışmanın yapılmamış olması bu çalışmanın önemini ortaya koymaktadır.

\section{YÖNTEM}

Bu araştırma ilişkisel tarama modeline göre planlanmıştır. Evrenin bütününde ya da evrenden alınan bir örneklem üzerinde yapılan araştırmalar tarama modelinin temelini oluşturur. İlişkisel tarama modeli olarak adlandırılan tarama modeli, en az iki değişken arasında olan ilişkiyi ve bu ilişkinin yönünü saptamak amaciyla kullanılır (Karasar, 2017).

\section{Çalışma Grubu}

Bu araştırmanın çalışma grubunu 2019-2020 eğitim öğretim yllında Muş ilinde görev yapmakta olan anaokulu, ilkokul, ortaokul ve liselerde çalışan ve "Rehberlik Öğretmeni” (MEB, 2017) kadrosunda bulunan 115 okul psikolojik danışmanı oluşturmaktadır.

Araştırmaya katılan okul psikolojik danışmanlarının (n=115) sosyodemografik özellikler Tablo-1'de verilmiştir.

Tablo 1. Katılımcıların sosyodemografik özelliklere göre dağılımı

\begin{tabular}{llcc}
\hline & Gruplar & $\mathbf{n}$ & $\mathbf{\%}$ \\
\hline \multirow{3}{*}{ Yaş } & $20-24$ Yaş & 22 & 19.1 \\
& $25-29$ Yaş & 77 & 67.0 \\
& $30-34$ Yaş & 13 & 11.3 \\
Cinsiyet & Kadin Yaş Üstü & 3 & 2.6 \\
\hline \multirow{2}{*}{ Medeni Durum } & Erkek & 80 & 69.6 \\
& Eekâr & 35 & 30.4 \\
& Evli & 73 & 63.5 \\
& Toplam & 42 & 36.5 \\
\hline
\end{tabular}

Tablo-1 incelendiğinde 22-45 (Ort.=26.61, ss=3,30) yaş aralı̆̆ında bulunan katılımcıların 80’i kadın (\%69.6) ve 35'i erkektir (\%30.4). Araştırmaya katılan okul psikolojik danışmanlarının 73’ü (\%63.5) bekâr olup 42’si (\%36.5) evlidir. 


\section{Veri Toplama Araçları}

$\mathrm{Bu}$ araştırmada veri toplama araçları olarak "Demografik Bilgi Formu", "UCLA Yalnızlık Ölçeği”, “Genel Sosyotelist Olma Ölçeği” ve "Sosyotelizme Maruz Kalma Ölçeği” kullanılmıştır.

Demografik Bilgi Formu: Araştırmacı tarafindan geliştirilen bu form 3 sorudan oluşmaktadır. Bu form ile katılımcıların yaş, cinsiyet ve medeni durumu ile ilgili bilgiler toplanmaya çalışılmıştır. Katılımcıların kimlik ve özel bilgilerine yönelik herhangi bir soru sorulmamıștır.

UCLA Yalnızlık Ölçeği: Russel ve arkadaşları (1978) tarafından geliştirilen ve Demir (1989) tarafından Türkçeye uyarlama ve geçerlilik, güvenirlik çalışmaları yapılan UCLA Yalnızlık Ölçeği 10 tanesi ters, diğer 10 tanesi düz yönde puanlanan her biri 4'lü likert tipinde 20 maddeden oluşmaktadır. Her bir maddesi çeşitli duygu ve düşünce belirten ifadelerden oluşan maddelerden olumluları ters, olumsuzları düz yönde puanlanır. Olumlu ve ters yönde puanlanan maddeler $(1,4,5,6,9,10,15,16,19,20)$, "hiç yaşamam” (4), "nadiren yaşarım” (3), "bazen yaşarım” (2), "sı1k sık yaşarım" (1) şeklinde; olumsuz ve düz yönde puanlanan maddeler $(2,3,7,8,11,12,13,14,17,18)$, "hiç yaşamam” (1), "nadiren yaşarım” (2), "bazen yaşarım” (3), "sı1k sık yaşarım” (4) şeklinde puanlanmaktadır. Bu maddelerden elde edilen toplam puan her birey için yalnızlık puanını oluşturmaktadır. Bu ölçekle ölçülen yalnızlık puanı 20-80 arasındadır. Ölçekten alınan puan arttıkça yalnızlık düzeyi de artmış olur. Ölçeğin Türkçe uyarlamasının yapıldığı çalışmada (Demir, 1989) ölçeğin iç tutarlılık katsayısını .96 saptamıştır.

Genel Sosyotelist Olma Ölçeği: Chotpitayasunondh ve Douglas (2018) tarafından geliştirilen ve Türkçe'ye Orhan Göksün (2019) tarafindan uyarlanmıştır. Ölçek 7’li likert tipinde toplam 15 maddeden oluşmaktadır (1= Asla, 2= Nadiren, 3= Ara sira, 4= Bazen, 5= S1k s1k, 6= Genellikle, $7=$ Daima). Ölçeğin uyarlama çalışmasında (Orhan Göksün, 2019) iç tutarlılık kat sayısının .93 olduğu saptanmıştır. 4 Faktörlü ölçeğin alt boyutları "nomofobi”, "kişisel çatışma”, "kendini yalnızlaştırma" ve "problem farkındalı̆̆ı"dır.

Sosyotelizme Maruz Kalma Ölçeği: Sosyotelist olma ölçeği gibi sosyotelizme maruz kalma ölçeği de Chotpitayasunondh ve Douglas (2018) tarafindan geliştirilmiş olup Türkçe’ye Orhan Göksün (2019) tarafından uyarlanmıştır. Ölçek, 7’li likert tipinde toplam 22 maddeden oluşmaktadır. GSMK üç faktörlü yapı (Algılanan Normlar, İhmal Edilmişlik Hissi ve Kişilerarası Çatışma) ile sosyotelizme maruz kalma durumunu \%54.91 ile $(\alpha=0.96)$ açıklamaktadır (Orhan Göksün, 2019).

\section{Verilerin Toplanmas1}

Bu çalışma Helsinki Bildirgesi’ne uygun bir şekilde yürütülmüş olup çalışmanın yürütülmesi için Van Yüzüncü Yıl Üniversitesi Sosyal ve Beşeri Bilimler Etik Kurulu’ndan gerekli onay alınmıştır (2 Şub, 2020 / E.242). Ayrıca verilerin toplanması için çalışma grubunun bağlı bulunduğu Muş Milli Eğitim Müdürlüğü'nden kurumsal izin alınmıştır. Verilerin toplanması Google Formlar ile oluşturulan çevrimiçi form ile elde edilmiştir. Araştırmacılar tarafından oluşturulan formda 
çalışmaya katılım koşulları ve çalışmayı istedikleri zaman bırakabileceklerine dair bilgilendirmeler yer verilmiştir. Çevrimiçi formun ortalama doldurulma süresi yaklaşık 7 dakikadır.

\section{Verilerin Analizi}

Araştırma kapsamında çalışma grubundan toplanan veriler SPSS 22.0 programına aktarılmıştır. Araştırmada kullanılan veri toplama araçları ile elde edilen verilerin yorumlanması için veri toplama araçlarından alınan puanlara ilişkin ortalama, standart sapma, minimum-maksimum puanlar ve standart hata değerleri saptanmış olup Tablo-2'de gösterilmiştir.

Tablo-2. Veri toplama araçlarından elde edilen betimsel istatistikler

\begin{tabular}{lcccccc}
\hline Değişkenler & $\mathbf{n}$ & Min & Max & $\overline{\mathbf{x}}$ & sd & S \\
\hline Genel Sosyotelizm Olma & 115 & 16.00 & 95.00 & 41.35 & 1.39 & 14.94 \\
Genel Sosyotelizme Maruz & 115 & 36.00 & 154.00 & 81.06 & 2.29 & 24.58 \\
Kalma & 115 & 25.00 & 65.00 & 36.48 & .79 & 8.54 \\
Yalnızlık & & & & &
\end{tabular}

Katılimc1lardan elde edilen genel sosyotelist olma ve genel sosyotelizme maruz kalma toplam puanlarının cinsiyete ve medeni duruma göre anlamlı farklılaşıp farklılaşmadıklarını saptamak için gruplar arasındaki istatistiki farkların yapılacağı test varsayımlarının karşılanıp karşılanmadığına bakılmıştır. Verilerin cinsiyet ve medeni durum gruplarında normal dağılım gösterip göstermediğini belirlemek için basıklık ve çarpıklık katsayıları incelenmiştir. İlgili gruplarda basıklık ve çarpıklık verilerinin \pm 1.0 arasında yer almadığı görülmüş olup verilerin normal dağılmadığı sonucuna (Hair, Black, Babin and Anderson, 2013) ulaşılmıştır. Verilerin normal dağılımı için logaritmik dönüşüm yapılmış olup dönüşüm sonucunda verilerin normal dağılım sağladığ1 görülmüştür. Değişkenlerin çarpıklık ve basıklık değerleri Tablo-3'de gösterilmiştir. Veri toplama araçlarının çarpıklık ve basıklık sonuçlarına göre parametrik testlerden bağımsız örneklem t testi kullanılmasına karar verilmiştir.

Tablo-3. Değişkenlerin çarpıklık - basıklık değerleri

\begin{tabular}{lccc}
\hline Değişkenler & Gruplar & Çarpıklık & Basıklık \\
\hline \multirow{3}{*}{ Genel Sosyotelist Olma } & Kadın & .267 & .239 \\
& Erkek & -.747 & .559 \\
& Bekâr & .104 & .042 \\
& Evli & -.140 & .165 \\
Genel Sosyotelizme Maruz Kalma & Kadın & -.035 & -.489 \\
& Erkek & .109 & .024 \\
& Bekâr & .130 & -.500 \\
& Evli & -.212 & -.116 \\
\hline
\end{tabular}


Pearson Çarpım Momentler Korelasyon katsayısı analizi kullanılmıştır. Yordayıcı değişken olan genel sosyotelist olmanın, yalnılıktaki ve genel sosyotelizme maruz kalmadaki yordayıcı rolünü test etmek için iki ayrı basit doğrusal regresyon analizi yapılmıştır. Regresyon analizinden önce verinin analiz için gerekli normallik ve doğrusallık varsayımlarını sağladığı tespit edilmiştir. Verilerin analizleri için tüm işlemler için SPSS 22.0 programı kullanılmış ve yorumlamada $\mathrm{p}<0.05$ ve $\mathrm{p}<0.001$ anlamlılık düzeyleri kullanılmıştır.

\section{BULGULAR}

Katılımcıların genel sosyotelist olma puanlarının cinsiyet ve medeni durum değisskenlerine göre farklılık gösterip göstermediğini belirlemek amacıyla yapılan Bağımsız Örneklem t testi sonuçları Tablo-4'te verilmiştir.

Tablo 4. Katılımcıların cinsiyet ve medeni durum açısından genel sosyotelist olma puanlarının incelenmesine yönelik bağımsız örneklem t testi sonuçları

\begin{tabular}{lccccccc}
\hline Değişken & Gruplar & $\mathbf{n}$ & $\overline{\mathbf{x}}$ & $\mathbf{S}$ & $\mathbf{s d}$ & $\mathbf{t}$ & $\mathbf{p}$ \\
\hline & Kadın & 80 & 41.07 & 15.47 & 1.73 & & \\
& Erkek & 35 & 42.00 & 13.82 & 2.33 & & .361 \\
Genel Sosyotelist Olma & Bekâr & 73 & 41.47 & 13.96 & 1.63 & .116 & .908 \\
& Evli & 42 & 41.14 & 16.68 & 2.57 & & \\
\hline
\end{tabular}

Tablo-4 incelendiğinde psikolojik danışman ve rehber öğretmenlerin genel sosyotelist olma puan ortalamalarının cinsiyete $(\mathrm{t}(113)=-.304, \mathrm{p}<.01)$ ve medeni duruma $(\mathrm{t}(113)=.116, \mathrm{p}<.01)$ göre farklılaşmadığı görülmektedir. Katıllımcıların genel sosyotelizme maruz kalma puanlarının cinsiyet ve medeni durum değişkenlerine göre farkl111k gösterip göstermediğini belirlemek amaciyla yapılan Bağımsız Örneklem t testi sonuçları Tablo-5’te verilmiştir.

Tablo 5. Katılımciların cinsiyet ve medeni durum açısından genel sosyotelizme maruz kalma puanlarının incelenmesine yönelik bağımsız örneklem $\mathrm{t}$ testi sonuçları

\begin{tabular}{lccccccc}
\hline Değişken & Gruplar & $\mathbf{n}$ & $\overline{\mathbf{x}}$ & $\mathbf{S}$ & $\mathbf{s d}$ & $\mathbf{t}$ & $\mathbf{p}$ \\
\hline & Kadın & 80 & 82.86 & 23.79 & 2.66 & & \\
Genel Sosyotelizme & Erkek & 35 & 76.94 & 26.18 & 4.42 & & \\
Maruz Kalma & Bekâr & 73 & 81.95 & 24.52 & 2.87 & .415 & .608 \\
& Evli & 42 & 79.50 & 29.90 & 3.84 & & \\
\hline
\end{tabular}

Tablo-5 incelendiğinde psikolojik danışman ve rehber öğretmenlerin genel Sosyotelizme ma- 
ruz kalma puan ortalamalarının cinsiyete $\left(\mathrm{t}_{(113)}=1.190, \mathrm{p}<.01\right)$ ve medeni duruma $\left(\mathrm{t}_{(113)}=.415, \mathrm{p}<.01\right)$ göre farklılaşmadığı görülmektedir. Genel sosyotelist olma ile yalnızlık ve genel sosyotelizme maruz kalma arasındaki korelasyon ilişkisine yönelik analizler Tablo-6'da verilmiştir.

Tablo-6: Değişkenler Arasındaki Korelasyon Katsayıları

\begin{tabular}{lccc}
\hline & Genel Sosyotelist Olma & Yalnılık & $\begin{array}{c}\text { Genel Sosyotelizme } \\
\text { Maruz Kalma }\end{array}$ \\
\hline Genel Sosyotelist & 1 & $.204^{*}$ & $.215^{*}$ \\
Olma & .029 & .021 \\
\hline Yalnizlik & 1 & $.191^{*}$ \\
\hline Genel Sosyotelizme & & .041 \\
Maruz Kalma & & 1 \\
\hline$* \mathrm{p}<.05$ & &
\end{tabular}

Tablo-6 incelendiğinde genel sosyotelist olma ile yalnızlik $(\mathrm{r}=.204, \mathrm{p}<.05)$, genel sosyotelist olma ile genel sosyotelizme maruz kalma $(\mathrm{r}=.215, \mathrm{p}<.05)$ ve yalnızlık ile genel sosyotelizme maruz kalma $(\mathrm{r}=.191, \mathrm{p}<.05)$ arasında pozitif yönlü anlamlı ilişki bulunmuştur. Yordayıcı değişken olan genel sosyotelist olmanın, yalnılıktaki ve genel sosyotelizme maruz kalmadaki yordayıc1 rolünü test etmek için yapılan regresyon analizinin sonuçları Tablo-6 ve Tablo-7'de verilmiştir.

Tablo-6: Genel sosyotelist olmanın yalnızlı̆̆1 yordamasına ilişkin basit regresyon analizi sonuçlar1

\begin{tabular}{lcccccccc}
\hline Değişken & $\mathbf{B}$ & $\begin{array}{c}\text { Standart } \\
\text { Hata }\end{array}$ & $\boldsymbol{\beta}$ & $\mathbf{t}$ & $\mathbf{R}$ & $\mathbf{R}^{2}$ & $\mathbf{F}$ & $\mathbf{p}$ \\
\hline Sabit & 1.282 & .109 & & 11.747 & .204 & .041 & 4.883 & $.029^{*}$ \\
Sosyotelizm & .151 & .068 & .204 & 2.210 & & & & \\
\hline
\end{tabular}

$* \mathrm{p}<.05$

Tablo-6 incelendiğinde okul psikolojik danışmanlarının genel sosyotelist olmaları, yalnızlıklarını yordamaktadır. Genel sosyotelist olma, katılımcıların yalnızlık puanlarındaki varyansın yaklaşı \% \% ünü açıklamaktadır $\left(\mathrm{R}^{2}=.041\right)$.

Tablo 7: Genel sosyotelist olmanin genel sosyotelizme maruz kalma yordamasina ilişkin basit regresyon analizi sonuçları

\begin{tabular}{lcccccccc}
\multicolumn{1}{c}{ Değişken } & $\mathbf{B}$ & $\begin{array}{c}\text { Standart } \\
\text { Hata }\end{array}$ & $\boldsymbol{\beta}$ & $\mathbf{t}$ & $\mathbf{R}$ & $\mathbf{R}^{2}$ & $\mathbf{F}$ & $\mathbf{p}$ \\
\hline Sabit & 1.597 & .126 & & 12.718 & .215 & .046 & 5.467 & $.021^{*}$ \\
Sosyotelizm & .184 & .079 & .215 & 2.338 & & & & \\
\hline
\end{tabular}

$* \mathrm{p}<.05$ 
Tablo-7 incelendiğinde çalışma grubunda bulunan okul psikolojik danışmanlarının genel sosyotelizme maruz kalma puanları, genel sosyotelist olma puanları tarafindan anlamlı bir şekilde yordanmanktadır. Genel sosyotelist olma puanları, katılımciların genel sosyotelizme maruz kalma puanlarındaki varyansın yaklaşık \%5’ini açıklamaktadır $\left(\mathrm{R}^{2}=.046\right)$.

\section{TARTIŞMA, SONUÇ VE ÖNERİLER}

Alanyazında yeni bir kavram olarak öne çıkan sosyotelizmin konu edinildiği bu araştırmada kavramın psikolojik danışmanlardaki durumunu belirlemek ve sosyotelizmin ilişkili olduğu düşünülen yalnızlık ve genel sosyotelizme maruz kalma ile ilişkisini incelemek istenmiştir. Yapılan istatistiksel testler sonucunda hem genel sosyotelist olma puanlarının hem de genel sosyotelizme maruz kalma puanlarının cinsiyete göre anlamlı bir şekilde farklılaşmadığı sonucuna ulaşılmıştır. Bu bulgu sosyotelizmle ilgili yapılan diğer çalışmalardan farklılık göstermektedir. Karadă̆ ve arkadaşlarının yaptığı çalışmada (2015), kadınların ve erkeklerin sosyotelist davranış gösterme şekli birbirinden farklılaşmaktadır ve cinsiyet sosyotelist davranışlar sergilemede güçlü bir etkendir. Benzer şekilde Roberts, Yaya ve Manolis (2014) sosyotelizm üzerine yaptıkları çalışmalarında, cinsiyetin sosyotelist davranış sergilemede önemli bir etken olduğunu ve kadınların erkeklerden daha fazla sosyotelist davranış sergilediği sonucuna ulaşmıştır.

Çalışmanın diğer bir sonucuna göre hem genel sosyotelist olma puanlarının hem de genel sosyotelizme maruz kalma puanlarının medeni duruma göre anlamlı bir şekilde farklılaşmamıştır. Literatürde sosyotelist olma ve medeni durum arasındaki ilişkiyi inceleyen herhangi bir çalışmaya rastlanmamıştır. Fakat sosyotelist bireylerin romantik ilişkilerinde daha az tatmin oldukları bilinmektedir (Chotpitayasunondh ve Douglas, 2018; McDaniel ve Coyne, 2016). Ayrıca çiftler arasında sosyotelist olmaktan kaynaklı kavgalar yaşanmaktadır (Halpern ve Katz, 2017).

Genel sosyotelist olma ile yalnızlık arasında pozitif yönde anlamlı bir ilişki saptanmıştır. Bu bulguya göre, psikolojik danışmanların sosyotelist davranışları arttıkça yalnızlık düzeyleri de artmaktadır. Bu bulgu sosyotelizmin, yalnızlıkla ilişkili olduğunu desteklemektedir (Afdal vd., 2019). Aynı zamanda bu bulgu, Mert ve Özdemir'in (2018) akıllı telefon bağımlılı̆̆ ile yalnızlık arasında ilişkiyi saptadıkları araştırmanın sonucuyla da örtüşmektedir. Bireylerin yalnızlık, can sıkıntısı, başkalarıyla ilgili haberleri kaçırma korkusu gibi nedenlerden dolayı akıllı telefonu sık kullandıkları yapılan çalışmalarla desteklenmektedir. Yalnızlık duygusu arttıkça sosyotelist olma durumu da artmaktadır (Al-Saggaf ve O’Donnel, 2019).

Genel sosyotelist olma ile genel sosyotelizme maruz kalma arasinda pozitif yönde anlamlı bir ilişki saptanmıştır. Psikolojik danışmanların genel sosyotelizme maruz kalma düzeyleri arttıkça sosyotelist davranışları da artmaktadır. Sosyotelizm yüzyüze iletişime zarar vererek karşı tarafın kendini kötü hissetmesine neden olmaktadır (Turkle, 2011); çünkü yüz yüze iletişimdeki göz kontağının yerini telefon almaktadır (Nazir ve Pişkin, 2019). Bunlar sosyotelizme maruz kalan bireylerin, sosyotelist olma davranışlarının nedeni olabilir. Fakat bu çalışmanın bulguları sosyotelist olma ile sosyotelizme maruz kalma arasında neden sonuç ilişkisi koyma açısından yeterli değildir.

$\mathrm{Bu}$ araştırmada istatistiki işlemlerin yalnızca toplam puanlar üzerinden yapılması araştırmanın sınırlılığı olarak görülebilir. Benzer araştırmaların sosyotelizm ve sosyotelizme maruz kalma durum- 
iletișim / Contact

Mail : info@humanisticperspective.com Web : https://dergipark.org.tr/tr/pub/hp

larını alt boyutlar üzerinden ele alması konunun derinlemesine incelenmesini sağlayabilir.

Sonuç olarak sosyotelizmin hem yalnızlık hem de sosyotelizme maruz kalma üzerinde etkisinin olduğu tespit edilmiştir. Sosyotelizmin yalnızlık üzerindeki etkisinden hareketle okul psikolojik danışmanlarına bağlı bulundukları üst kurumların hizmetiçi eğitim faaliyetleri kapsamında sosyotelist davranışı tanıma, sosyotelizm ile ilişkili kavramlar ve sosyotelist davranışların yalnızlı̆̆1 nasıl etkilediği konularında eğitimler düzenlenmesi önerilebilir. Sosyotelizmin, özellikle sosyotelizme maruz kalma üzerindeki etkisinin saptanması iletişimin karşılıklı yapısından kaynaklanıyor olabilir. Bu haliyle sosyotelizmi, bir iletişim engeli olarak tanımlamak araştırmanın bu bulgusu sonucunda söylenebilir. Bu bağlamda sosyotelizmin iletişim becerileri ile ilişkisinin araştırıldığı araştırmalar konuyu anlamak açısından dikkat çekici olabilir. Araştırmacılar, bu araştırmada incelenen değişkenlerden farklı değişkenler ile sosyotelizm arasındaki ilişkiyi inceleyebilirler. Bu araştırmada sosyotelizmin okul psikolojik danışmanlarındaki durumu incelenmiştir. Sosyotelizmin öğretmenler, yöneticiler, üniversite ve lise öğrencileri gibi farklı çalışma grupları ile işlenmesi önerilebilir.

\section{KAYNAKÇA}

Afdal, A., Alizamar, A., Ifdil, I., Ardi, Z., Sukmawati, I., Zikra, Z., Ilyas, A., Fikri, M., Syahputra, Y. \& Hariyani, H. (2019). An analysis of phubbing behaviour: Preliminary research from counseling perspective. Advances in Social Science, Education and Humanities Research, 295, 270 273.

Al-Saggaf, Y. \& O’Donnell, S. B. (2019). Phubbing: Perceptions, reasons behind, predictors, and impacts. Human Behavior and Emerging Technologies, 1(2), 132-140. DOI: 10.1002/hbe2.137.

Büyükgebiz Koca, E. (2019). Akı1lı telefon bağımlılı̆̆1 ve sosyotelizm üzerine bir yazın taraması. Avrasya Sosyal ve Ekonomi Araștırmalar Dergisi, 6(6), 399-411.

Chotpitayasunondh, V. \& Douglas, K. M. (2016). How "phubbing" becomes the norm: the antecedents and consequences of snubbing via smartphone. Computers in Human Behavior, 63, 9-18. DOI: $10.1016 /$ j.chb.2016.05.018

Chotpitayasunondh, V. \& Douglas, K. M. (2018). Measuring phone snubbing behavior: development and validation of the generic scale of phubbing (gsp) and the generic scale of being phubbed (gsbp). Computers in Human Behavior, 88, 5-17. DOI: 10.1016/j.chb.2018.06.020

Chotpitayasunondh, V. \& Douglas, K. M. (2018). The effects of "phubbing” on social interaction. Journal of Applied Social Psychology, 48(6), 304-316. DOI: 10.1111/jasp.12506

Demir, A. (1989). Ucla yalnızlık ölçeğinin geçerlik ve güvenirliği. Psikoloji Dergisi, 7(23), 14-18.

Demirbaş, B. ve Haşit, G. (2016). İş yerinde yalnızlık ve işten ayrılma niyetine etkisi: akademisyenler üzerine bir uygulama. Anadolu Üniversitesi Sosyal Bilimler Dergisi, 16(1), 137-158.

Halpern, D. \& Katz, J. E. (2017). Texting's consequences for romantic relationships: A crossed- 
lagged analysis highlights its risks. Computers in Human Behavior, 71, 386-394. DOI: 10.1016/j. chb.2017. 01.051

Hair, J. F., Black, W. C., Babin, B. J., Anderson, R. E. \& Tatham, R. L. (2013). Multivariate Data Analysis: Pearson Education Limited.

Işı1k, M. ve Kaptangil, İ. (2018). Akıllı telefon bağımlılı̆̆ının sosyal medya kullanımı ve beş faktör kişilik özelliği ile ilişkisi: Üniversite öğrencileri üzerinden bir araştırma. Insan ve Toplum Bilimleri Arastırmalar Dergisi, 7 (2), 695-717. DOI: 10.15869/itobiad.361081

Karadağ, E., Tosuntaş, Ş. B., Erzen, E., Culha, İ., Mizrak Şahin, B., Babadağ, B. \& Duru, P. (2015). Determinants of phubbing, which is the sum of many virtual addictions: a structural equation model. Journal of Behavioral Addictions, 4(2), 60-74. DOI: 10.1556/2006.4.2015.005.

Karadağ, E., Tosuntaş, Ş. B., Erzen, E., Duru, P., Bostan, N., Mizrak Şahin, B., Culha, İ. \& Babadağ, B. (2016). The virtual world's current addiction: Phubbing. Addicta: The Turkish Journal on Addictions, 3(2). DOI: 10.15805/addicta.2016.3.0013

Karasar, N. (2017). Bilimsel Araştırma Yöntemi. Ankara: Nobel Yayınevi.

Korkut, F. (2005). Yetişkinlere yönelik iletişim becerileri eğitimi. Hacettepe Üniversitesi Ë̆gitim Fakültesi Dergisi, 28 (28) , 143-149.

McDaniel, B. T. \& Coyne, S. M. (2016). “Technoference”: The interference of technology in couple relationships and implications for women's personal and relational well-being. Psychology of Popular Media Culture, 5(1), 85-98. DOI: 10.1037/ppm0000065

Mert, A. ve Özdemir, G. (2018). Yalnızlık duygusunun akıllı telefon bağımlılı̆̆ına etkisi. OPUS Uluslararası Toplum Araștirmaları Dergisi, 8 (1), 88-107. DOI: 10.26466/opus.382285

Nazir, İ. B. \& Pişkin, M. (2019). Phubbing: A technological invasion which connected the world but disconnected humans. The International Journal of Indian Psychology, 3 (4), 175-182.

Orhan Göksün, D. (2019). Sosyotelist olma ve sosyotelizme maruz kalma ölçeklerinin Türkçeye uyarlanmas1. Afyon Kocatepe Üniversitesi Sosyal Bilimler Dergisi, 21 (3) , 657-671. DOI: 10.32709/ akusosbil.505642

Özdemir, S . (2020). Yönetici sosyotelizmi (phubbing): Bir ölçek uyarlama çalışması. Dicle Üniversitesi İktisadi ve İdari Bilimler Fakültesi Dergisi, 10 (19), 134-145.

Özteke Kozan, H. (2020). Okul psikolojik danışmanlığı ile ilgili yapılmış çalışmaların bibliyometrik analizi: 1980-2019. Okul Psikolojik Danışmanlĭ̆ Dergisi, 3(1) , 1-28.

Roberts, J. A., Yaya, L. P. \& Manolis, C. (2014). The invisible addiction: Cellphone activities and addiction among male and female college students. Journal of Behavioral Addictions, 3 (4), 254-65. DOI: 10.1556/JBA.3.2014.015

Russel, D. W., Peplau, L. A. \& Ferguson, M. L. (1978). Developing a measure of loneliness. Journal of Personality Assessment, 42(3), 290-294.

Ünalan, D. ve Yıldırım, O. (2020). Dijital yerlilerin sosyotelizm (phubbıng) eğilimlerinin 
değerlendirilmesi. Gümüshane Üniversitesi İletişim Fakültesi Elektronik Dergisi, 8 (1), 276-297 . DOI: $10.19145 /$ e-gifder.644279.

Turkle, S. (2011). Alone together: why we expect more from technology and less from each other. New York, NY: Basic Books.

Yakut, S. ve Certel, H. (2016). Öğretmenlerde yalnızlık düzeyinin çeşitli değişkenler açısından incelenmesi. Birey ve Toplum Sosyal Bilimler Dergisi, 6(1), 69-94.

Yeşilyaprak, B. (2010). Eğitimde rehberlike hižmetleri: gelişimsel yaklaşım. Ankara: Nobel Yayınc1lı. 